811.163.41(091):929 Ковачевић М. https://doi.org/10.18485/sj.2019.24.1.4

\section{АЛЕКСАНДАР М. МИЛАНОВИТ}

Универзитет у Београду

Филолошки факултет
Оригинални научни рад Примљен: 27. 11. 2018. Прихваћен: 15. 01. 2019.

\title{
МИЛОШ КОВАЧЕВИЋ КАО ИСТОРИЧАР СРПСКОГ КЬИЖЕВНОГ ЈЕЗИКА
}

У раду се анализирају Ковачевићеве теоријско-методолошке основе и поступци у анализама књижевнојезичких промена у 18. и 19. веку. Указује се на Ковачевићеве доминанте у истраживањима: склоност ка синтези, уочавање тенденција у развоју књижевног језика, издвајање сличности и разлика у концепцијама књижевног језика, инсистирање на критеријалности. На основу наведених особина у истраживањима развоја књижевног језика, приступ Милоша Ковачевића најближи је приступу Радоја Симића, али и приступу Павла Ивића, а посебно је утицао на приступ Јелице Стојановић.

Кључне речи: Милош Ковачевић, историја српског књижевног језика, концепција књижевног језика, народни језик, Вук Караџић, Доситеј Обрадовић, „опћена правилност”

1. Историја српског књижевног језика имала је као интердисциплинарна лингвистичка дисциплина логичан и очекиван развој: после првобитне фазе минуциозне дескрипције спољашњих друштвено-историјских околности које су утицале на књижевнојезичке промене, где се ова наука највише додиривала са историјом и социологијом, прешло се на опис и анализу језичких особина типова књижевних језика које су Срби употребљавали кроз историју, где је

*aleksandar.jus@gmail.com 
у монографијама и студијама доминирала чисто графијска, ортографска и граматичка компонента. Кретало се најчешће од опуса истакнутих стваралаца (књижевника, научника, публициста), о чему сведоче бројне монографије, а паралелно су утврђиване сличности и разлике у језичком изразу стваралаца у оквирима исте епохе. Тек када је историја српског књижевног језика дошла до обиља података и о спољашњим узроцима промена и о структурним особинама књижевнојезичких идиома, могле су се објективно сагледати тенденције и константе у књижевнојезичким променама, сродности и разлике у књижевнојезичким концепцијама, размимоилажења између концепције и реализације. Вођени пре свега узорним Унбегауновим и Белићевим синтезама, синтетичких захвата у историји нашег књижевног језика латили су се напоредо и историчари језика и историчари књижевности још током седме деценије 20. века, а замах оваквих тенденција бележимо током осме и девете деценије истог столећа. Међу лингвистима који су се управо у овом периоду посветили, напоредо са педантним (микро)анализама, и синтетичким студијама развоја нашег књижевног језика у млађем периоду 18. и 19. века, поред представника новосадске школе (Павла Ивића, Александра Младеновића, Јована Кашића, Јована Јерковића, Питера Херитија, Јусија Нуорлуотоа, Светозара Стијовића, Љиљане Суботић) били су и лингвисти из Београда, Подгорице (тадашњег Титограда) и Сарајева: Радоје Симић, Радмило Маројевић, Бранислав Остојић, Херта Куна, Милош Окука и Милош Ковачевић. ${ }^{1}$

2. Милош Ковачевић лингвистички се формирао као синхроничар, првенствено синтаксичар и стилистичар, али се у у своме научном стваралаштву окренуо и историји српског књижевног језика као значајној компоненти целокупога опуса. Као што је већ напоменуто, његово првенствено интересовање су књижевојезичка превирања током 18. и 19. века, и њима је посветио већи број својих расправа, потом окупљених у више књига. Проблемима историјског развоја српских књижевних и стандардног језика М. Ковачевић се бави већ више од две деценије. Не чуди стога што и у научном самоодређењу, својеврсној научној личној карти, и са̂м М. Ковачевић (2015: 266) наглашава: „Основне научне преокупације су му: синтакса, првенствено синтаксичка семантика, стилистика, и историја српскога књижевног језика."

3. У Ковачевићевим студијама посвећеним историји српскогкњижевног језика уочавају се одређене теоријско-методолошке константе. Он ретко креће од сопствене дескрипције и анализе језичких особина самога текста, осим када су лингвостилистичке анализе у питању, па зато преузима резултате релевантних студија да би их активирао за потребе синтеза. Навешћемо само један пример: када М. Ковачевић анализира разлику између Доситејевог „намјеренија" и његове језичке реализације, он се позива на резултате анализа

\footnotetext{
${ }^{1}$ УП. списак литературе.
} 
конкретних Доситејевих текстова из свих круцијалних студија, почев од прве монографије Милована Сучевића (1914) и друге Херте Куне (1970) па све до оних из синтетичке студије Бориса Унбегауна (1995), не тражећи нове потврде кроз сопствене анализе. Суштину Ковачевићевог метода не чини трагање за језичким детаљем. Вођен чврстим научним критеријумима, он бира обрађене језичке податке из постојеће литературе да би се на основу њих фокусирао на утврђивање траженог: тенденција и константи у бурним књижевнојезичким променама током два века, сродности и разлика у књижевнојезичким концепцијама, размимоилажења између самих концепција и њихових реализација. Дакле, у средишту Ковачевићевих поставки су књижевнојезичке концепције и њихове реализације, као и критеријуми на основу којих су постављане и рушене темељне поставке језика српске писане културе током периода када је она пролазила и кроз унутрашња превирања и различите спољашње утицаје.

Како су у питању заправо историја филолошких идеја, изнесених махом у форми манифестних исказа, као и историја њихових успешних или безуспешних реализација, у трагању за одговорима Ковачевићу кључну подршку, и то као механизми илустрација за читаоце и потпоре за сопствене закључке, пружају и пробрани али бројни цитати из дела аутора које анализира.

4. Као и у синтаксичким и стилистичким радовима, М. Ковачевић и у радовима из историје српског књижевних језика инсистира на критеријумима, како сопственим тако и критеријумима аутора чије концепцијске поставке анализира. Ваља зато издвојити посебан квалитет његових студија: прецизно издвајање и још прецизније формулисање критеријума на којима је почивао одређени поступак. Ти критеријуми не само да су издвојени и дефинисани већ су по правилу и вредновани. За наведене поступке има много потврда у његовим студијама. Наведимо само једну, и то у ширем контексту ради разумевања поенте:

„Вук је рушећи градио и градећи рушио. Рушечи тадашњи и дотадашњи тип славеносрпског језика, Вук је градио српски књижевни језик на народној основици, а градећи српски књижевни језик, Вук је рушио (и срушио) славеносрпски. У првом периоду Вукова похода (до 1818) на сцени је Вукова градња рушењем, а како поход одмиче, тако у први план иступа рушење градњом. И у рушењу и у грађењу Вук наступа с два темељна критеријума - критеријумом грађе и критеријумом структуре језика" (Ковачевић 1999: 31).

На делу видимо парадигматски Ковачевићев поступак: издвојени су и прецизно и сажето формулисани критеријуми. Тек када су смештени у одговарајући друштвено-историјски контекст, следи утврђивање хронологије њиховог настанка и одређивање сврсисходности њихове примене:

„С та два критеријума Вук се користи од свог првога књижевнојезичкога текста па све до побједе своје реформе. Иако се критеријуми грађе и структуре комбинују у готово свим Вуковим текстовима, ипак у почетној и на почетку средишње фазе Вукове реформе 
критеријум грађе надређен је критеријуму структуре, док је у завршној фази реформе критеријум структуре у други план потиснуо критеријум грађе” (Ковачевић 1999: 31).

Следи нови, чест Ковачевићев методолошки и стилски поступак: додатно појашњавање изнетих ставова у форми њиховог сажимања, наглашено маркером у виду иницијалне конструкције друкчије речено: „Друкчије речено, у свом рушилачком походу Вук се првенствено користио критеријумом грађе, а у свом градитељском походу много му је битнији критеријум структуре" (Ковачевић 1999: 31). Потом, издвајање критеријума сравњује се са релевантном литературом, као и Вуковом терминологијом:

„Та два критеријума садржана су - како је то уочио и образложио Радоје Симић - већ у Вуковој рецензији Усамљеног јуноше, и то у 'двама фундаменталним појмовима на којима је заснована Вукова теорија књижевног језика... Први од њих назван је чистотом, другом је Вук дао име својство језика"” (Ковачевић 1999: 32).

Коначно, Вукова терминологија, а преко ње и методологија, сравњује се са ауторовом, да би се нагласила комплементарност поставки: „Вуков критеријум чистоте подразумијева дакле аутентичност грађе књижевног језика ('чисти и непокварени говор народа Србскога'), с тим да аутентичност грађе имплицира и аутентичност структуре (јер ко 'гријеши против говора свог народа онај гријеши против правила свога језика')" (Ковачевић 1999: 32).

5. Нема нити једног тумача историје српског књижевног језика у „превуковском” и „вуковском” периоду који није правио паралеле између књижевнојезичких концепција Доситеја Обрадовића и Вука Караџића, кључних фигура читавих епоха, па и читавих векова којима су припадали. На базичном проблему народне основице будућег језика српске културе, скицираном у време зачетака српске нормативистике, задржао се и М. Ковачевић у студији „Доситејево намјереније а Вуково остварење - српски народни за књижевни језик свих Срба” (1999: 15-30), у којој је истакао два суштинска питања: „Прво је питање: који то и какав народни језик они желе увести у књижевност, тј. којем то и каквом народном језику они желе прибавити статус књижевног? А друго: чији је то језик и коме га (тј. ком народу) они намјењују?” (15). На њих аутор одмах даје одговоре: да су велики реформатори српског књижевног језика много сагласнији у одговору на прво него на друго питање, да су чак скоро „потпуно сагласни”, док се око првог питања „чак битно разилазе” (Ковачевић 1999: 16). Ту је и М. Ковачевић на терену одређивања сличности и разлика међу концепцијама, на којем су се окушали скоро сви историчари језика и историчари књижевности (уп. Милановић 2015 и Милановић 2018а), али један од ретких који је подједнаку пажњу посветио и оним аспектима који Доситеја и Вука приближавају и онима који их међусобно удаљавају.

Наиме, М. Ковачевић детаљно анализира једну по једну поставку у Доситејевом и Вуковом програму, упоређујући парадигматска места у манифестним текстовима реформатора, и изводи јасно формулисане закључке 
којима отвара потпоглавља своје студије. Издвајамо два кључна места која М. Ковачевић сматра тачкама додира: „Нигдје Вук није толико подударан с Доситејем колико у националном одређењу и 'омеђењу' Срба" (Ковачевић 1999: 17); „Језик као интегративни фактор свих Срба, без обзира на њихову вјерску раздијељеност, темељ је и Доситејевог и Вуковог српског филолошког програма” (21). Сличним семантички сасвим прозрачним исказима, лишеним сваке непотребне терминолошке или стилске мистификације, он таксативно набраја и разлике међу концепцијама, а нумерација потпоглавља јасно указује и на ауторову хијерархизацију важности издвојених удаљавања међу реформаторима. Кључна разлика формулисана је следећим речима о теоријским основама и заокружености програма реформе:

„Доситеј заправо и није имао правог програма књижевнојезичке реформе код Срба. Прожет просветитељским идејама, Доситеј жели 'просвештеније' Срба, жели образовање цијелог српског народа. А образовања народа нема и не може бити на језику који народ не зна и не разумије. Зато Доситеј и захтијева да се књиге пишу народним језиком, да код Срба народни језик буде и књижевни језик” (Ковачевић 1999: 21).

Посебно се подвалачи размимоилажење између Доситејевих намера и њихове реализације у пракси. Из следећих речи јасно се увиђа понекад недовољно истакнута чињеница - да Доситеј и није деловао као филолог, нити нормативиста који теоријски образлаже језичке постулате нити као граматичар који кодификатор који прописује књижевни језик, већ као просветитељ који утиче пре свега сопственим делом и сопственим језиком:

„И заиста, осим неколике начелне напомене, цио 'програм' књижевнојезичке реформе Доситеја Обрадовића и своди се на 'намјереније' да народни језик постане књижевни језик Срба, и да властитим 'прикладом' (примјером) покаже начин остварења тог 'намјеренија'. Доситеј не ради на књижевнојезичкој реформи, он указује на њену неопходност, и властитим примјером показује начин њене реализације" (Ковачевић 1999: 22).

Када је реч о Доситејевој реализацији, М. Ковачевић (1999: 22-23) ставља акценат на места у којима се језик просветитељевих дела удаљио од будућег вуковског модела: лексичку раслојеност која подразумева фреквентне црквенословенизме и русизме у вишем лексичком слоју, као и „граматичку раслојеност", под којом се подразумева одсуство фонолошке о творбено-граматичке адаптације славенизама.

Сматрамо посебно драгоценим што је још једном наглашена лексичка конкуренција и коегзистенција облика, што су феномени на којима се мора базирати дијахронијска лексикологија и лексикографија при обради српског вокабулара у 18-19. веку: „У цитатима које смо навели види се да Доситеј нпр. употребљава и корист и полза; и иначе у његовом језику врло је обична употреба лексема: ствар и вешч, несрећа и злополучије и др.” (Ковачевић 1999: 23). Исти тип лексичке конкуренције, додајмо на овоме месту, карактерише и језик Вукових радова из прве фазе његовог стваралаштва, од 1814. до 
1818. (Милановић 2018б), али и језик многих других писаца из предвуковске и вуковске епохе (Милановић 2014). Штета је што у анализи регистрованог лексичко-семантичког феномена М. Ковачевић није посегао и за лингвостилистичком анализом Доситејевог поступка, која би, додуше, нарушила тематско јединство студије, али би и дала и ауторов одговор на питање да ли је активирање синонима било стилски мотивисано или не.

6. Потпуно је јасно што је у анализама књижевнојезичких концепција М. Ковачевић морао истицати друштвено-историјски контекст у којем су оне настајале и које их је суштински предиспонирао. Можда је то највидљивије у студији „Значај Првог српског устанка за Вукову реформу српскога језика” (Ковачевић 2005: 13-27), у којој се Вукове идеје повезују не само са револуционарним заносом Срба, већ и са филолошким ставовима Јернеја Копитара, Саве Мркаља, Луке Милованова Георгијевића, те публицистичким активностима Димитрија Давидовића и Димитрија Фрушића. Читав овај бечки кружок смештен је, опет, у шире романтичарске идеје српског националног ослобођења, што М. Ковачевића (2005: 26) води закључку:

„У провођењу реформе српскога језика Вук је био у сагласности с најнапреднијим идејама и кретањима тога времена. А то вријеме, па сљедствено и Вукову реформу српског књижевног језика, не само да је - то је више него јасно - наговијестио него је и предодредио Први српски устанак, и Вуково учешће у њему.”

На исти начин контекстуализују се и конкретни поступци актера књижевнојезичких превирања у већ анализираној Ковачевићевој студији „Доситејево намјереније а Вуково остварење - српски народни за књижевни језик свих Срба". Чини се да се при контекстуализацији Вукових поступака аутору провукла и одређена, једва видљива, лична симпатија у иначе веома објективној анализи, па је тако он Вуков однос према Доситејевом језику посредно оправдао ставовима и поступцима утицајних Доситејевих следбеника: ${ }^{2}$

„Такву оштру оцјену Доситејевог језика готово да су Вуку наметнули његови противници, а Доситејеви поштоваоци и сљедбеници. Доситеј је код писаца славеносрпског језика постао врховни ауторитет. Њега су као аргумент против Вука истурали не само књижевници него и црква. Тако је дошло до парадоксалне ситуације. Пошто су се иза Доситеја заклањали главни Вукови противници, Доситејев је језик, 'без обзира на добре намјере Доситејеве и његова опредељења за општенародни језик, практично морао да буде брана народном језику".

Као и да са̂м осећа да је овакво тумачење само делимично тачно, да њиме није исцрпљено све што треба рећи, М. Ковачевић (1999: 25) наставља наведени исказ и враћа се на суштинску мотивацију за Вуков неправедни поступак, који је могуће правдати само бројним маневрима у време ,рата за српски језик и правопис”: „Вук то предупређује минимализацијом Доситејевих заслуга око

${ }^{2}$ Када су, пак, симпатије појединих аутора на Доситејевој страни, овај Вуков однос према претходнику тумачи се искључиво као пакост, злурадост или незахвалност. 
српског језика сводећи их само на Доситејеве добре намере.” Вођен својом културолошком мисијом, Вук је, добро је познато, воду на своју воденицу понекад умео управљати и мање коректним средствима, нарочито у својим полемичким текстовима, па је зарад успеха своје реформе неправедно умео нападати и своје пријатеље, на пример Саву Мркаља због његових текстова из 1817. године, објављених у Новинама српским.

После разматрања свих сличности и разлика између Доситејеве и Вукове концепције, М. Ковачевић (1999: 26) нема дилему када суди о њиховоме месту у стварању српског стандардног језика и када даје апсолутни примат Вуку, али је и Доситејева позиција сагледана из далеко објективније позиције но што је била Вукова: „Вук је твораи српског књижевног (стандардног) језика. Код Доситеја је тај језик само у сфери 'намјеренија'. Али, без обзира што је Вук тако беспоштедно критиковао Доситејев језик, треба рећи да би без Доситеја Вуку било кудикамо теже да изведе своју књижевнојезичку реформу."

7. Тако и много година касније у односу на ставове из касних 90-их година 20. в., на средини прве деценије новог века, М. Ковачевић нема намеру да скрајне Доситејев допринос стварању српског идентитета. Овом проблему, и то у много ширем контексту од оног који чине само Доситеј и Вук, он посвећује посебну пажњу у синтетичкој студији „Пут српског језика и писма саткан од странпутица”, у којем записује: „Срби су и за Доситеја и за Вука сви они који говоре српским језиком. А оно што Доситеј и Вук подразумијевају под Србима - свим Србима готово никад није било по вољи" (Ковачевић 2016: Х). И поводом идентитетских питања М. Ковачевић (2016: XI) опет инсистира на јасноћи критеријума, опет издвајајући лингвистичке као круцијалне:

„Критеријум разумљивости, или како би се лингвистички данас рекло, комуникативни критеријум, за Доситеја је, како се види, основни критеријум идентитета језика, а критеријум језика основни критеријум идентитета народа или нације. Вук је потпуно подударан с Доситејем у националном одређењу и 'омеђењу' Срба."’

8. Како је неумитност друштвених, тј. политичких и културних, токова условила победу вуковских принципа међу Србима, Вукова стандарднојезичка концепција у Ковачевићевим тумачењима стално се сагледава из перспективе конкретне примене тј. реализације двају основних начела у њој, начела „пиши као што говориш”, преузетог и преформулисаног на самом почетку реформе, и начела о „опћенитој правилности”, које је дуго сазревало, да би било формализовано 1845. године, у време пуне Вукове нормативистичке зрелости. Тако се и сравњивање Доситејевих и Вукових зрелих поставки врши преко начела „опћене правилности”:

${ }^{3}$ УП. и Ковачевић 2003. 
„Пошто је, за разлику од Доситеја, Вук свјестан дијалекатског језичког шаренила, он све што има у дијалектима не препоручује за књижевни језик, него само оно што се повинује принципу 'опћене правилности'. Вук тако врши лексичку и граматичку кодификацију, уз нужну дијалекатску унификацију, а све с циљем да би српски народни језик као књижевни имао стабилну структуру” (Ковачевић 1999: 26).

Ставови Вука Караџића о језичкој правилности и правилима у српском језику тема су и студије „Вукова 'опћена правилност' и година 1847.” (Ковачевић 2018), у којој се анализирају Вукове мене у погледима на овај проблем. Креће се од Вукове почетне фазе, у којој пише о неправилности славеносрпског језика и правилности сваког народног говора, преко средишње фазе, током које истиче да међу народним говорима има и оних који су правилнији, па све до финалне фазе из 40-их година, током којих Вук издваја критеријум „опћене правилности”, који постаје основни критеријум правилности неке језичке појаве. Потом М. Ковачевић проверава колико је „опћена правилност” као критеријум правилног народног језика потврђена у делима која су штампана 1847. године и симболизују неформалну победу Вукове реформе (Песме Бранка Радичевића, Горски вијенаи Петра II Петровића Његоша, Вуков превод Новога завјета, и Рат за српски језик и правопис Ђуре Даничића) и доказује „да ни у Радичевићевом ни у Његошевом пјесничком дјелу нису испоштовани принципи Вукове 'опћене правилности', а и да је сам Вук у преводу Новога завјета 'изневјерио' неке од најтемељнијих властитих принципа правилности" (Ковачевић 2018: 43). Аутор на истом месту закључује да је разлог томе „чињеница да 1847. година представља вододелницу два типа Вуковог 'народног језика у књижевности': 1) народни језик као језик комуникације, који подлијеже принципима „опћене правилности”, и 2) народни језик као језик књижевности подлијеже друкчијим принципима, принципима који су у основи његове поетске, а не његове комуникативне функције."

9. Како је, видели смо, Вук као реформатор књижевног језика непрекидно еволуирао, М. Ковачевић успоставља и одређене и хронологије његовог стваралаштва, у којима се као међаши одређују године кључних нормативистичких корака. Тако се, на пример, описујући Вуково почетно придржање „правила изведених из народног језика и пренесених у рјечник и граматику” М. Ковачевић (1999: 25) задржао на трима преломним годинама за кодификацију: години 1818 , када је објавио Српски рјечник, години 1826, када излазе Главне разлике између данашњега славенскога и српскога језика, и години 1828, када штампа Главна свриивања сушчествителни и прилагателни имена у српском језику. Овакве хронологије стварају поуздану основу за прецизније периодизације и Вуковог стваралаштва и развитка српских нормативистичких начела, што су задаци који стоје пред нашим историчарима књижевног језика.

10. У својим студјама из историје српског књижевног језика М. Ковачевић се служио богатом и разноврсном литературом, па тако у њој срећемо 
имена која су ову дисциплину стварала, утемељила и развијала до данашњих дана. Поред најистакнутијих србиста, као што су Стојан Новаковић, Љубомир Стојановић, Радосав Бошковић или Ирена Грицкат, међу цитиранима су и утемељивачи историје српског књижевног језика из иностранства (Борис Унбегаун), наши истакнути представници ове дисциплине (Александар Младеновић, Јован Кашић, Радмило Маројевић), али и књижевници (Меша Селимовић), било да се са њима М. Ковачевић слаже или, пак, са њима полемише (као у случају ставова А. Младеновића о еволуцији славеносрпског језика, на пример). Међутим, чини се да су најцитиранији радови Павла Ивића и Радоја Симића. Док у радовима из историје српског књижевног језика П. Ивића, једног од највећих лингвиста које смо имали, аутор дубоко уважава, али неретко и полемише с њим (нарочито око статуса доситејевског језика), дотле Радоја Симића, свога учитеља, наводи исључиво у позитивном контексту, слажући се и у целини и у појединостима са Симићевим гледиштима.

11. У свим Ковачевићевим студијама из историје српског књижевног језика, и не само у њима, наглашена је ауторова жеља да делује, да се из позиције аналитичара повести нашег језичког стандарда, као и идиома који су му претходили, активно укључи и у савремене токове језичке политике и језичког планирања. Управо доживљај историје као учитељице живота води М. Ковачевића у намери да непрестано прави паралеле између некадашње и савремене српске језичке ситуације. Зато је указивање на српске заблуде и наивности у нашој књижевнојезичкој прошлости један од лајтмотива Ковачевићевих радова. Агитаторску функцију илуструју и детаљи. На пример, да би изнети ставови били пријемчиви и сасвим разумљиви што широј читалачкој публици он по правилу транскрибује славеносрпске текстове (нпр. Ковачевић 1999: 16-17 итд.), а неретко и објашњава значење данас мање познатих, архаичних речи и израза.

У својој намери да делује М. Ковачевић је успео. Својим студијама из историје српског књижевног језика утицао је на многе истраживаче у овој области, а посебно је препознатљив његов траг у студијама Јелице Стојановић. Како је покренуо многа идентитетска, дуго запостављана, питања управо из перспективе историје српског (књижевног) језика, ваља очекивати да ће актуелност ове теме утицати на све већу заступљеност Ковачевићевих студија у будућим дијахронијским истраживањима језика српске културе. 


\section{ИЗВОРИ}

Ковачевић 1999: Милош Ковачевић, У одбрану језика српскога - $и$ даље, Београд: Требник.

Ковачевић 2003: Милош Ковачевић, Српски језик и српски језици, Београд: Српска књижевна задруга - БИГЗ.

Ковачевић 2005: Милош Ковачевић, Против неистина о српском језику, Источно Сарајево: Српско просвјетно и културно друштво „Просвјета”.

Ковачевић 2013: Милош Ковачевић, У одбрану српске ћирилице : хрестоматија, Пале: Српско просвјетно и културно друштво „Просвјета".

Ковачевић 2015: Милош Ковачевић, Српски језик између лингвистике и политике, Бањалука: Друштво наставника српског језика и књижевности Решублике Српске.

Ковачевић 2016: Милош Ковачевић, „Пут српског језика и писма саткан од странпутица", предговор у: Јелица Стојановић, Пут српског језика и писма, Београд: Српска књижевна задруга, VII-XLVIII.

Ковачевић 2018: Милош Ковачевић, „Вукова 'опћена правилност' и година 1847.”, у: Година 1847: преломна тачка савремене српске културе (ур. Александар Милановић и Рајна Драгићевић), Београд: Савез славистичких друштава Србије, 43-52.

\section{ЛИТЕРАТУРА}

Куна 1970: Kuna, Herta, Jezičke karakteristike književnih djela Dositeja Obradovića, Djela, XXXVI, Akademija nauka i umjetnosti Bosne i Hercegovine. Odjeljenje istorijsko-filoloških nauka, knj. 21, Sarajevo.

Милановић 2014: Александар Милановић, Језик Јована Суботића, Београд: Чигоја штампа - Филолошки факултет у Београду.

Милановић 2015: Александар Милановић, „Драгиша Живковић као историчар српског књижевног језика", у: Кьижевни теоретичар, историчар и компаратиста Драгиша Живковић (ур. Мило Ломпар и Ненад Николић), Београд: Филолошки факултет у Београду, 139-153.

Милановић 2018а: Александар Милановић, „Радоје Симић као историчар српског књижевног језика", у: Научни доприноси Радоја Симића 
(ур. Милош Ковачевић, Јелена Петковић и Владимир Поломац), Крагујевац: Филолошко-уметнички факултет, 139-150.

Милановић 2018б: Александар Милановић, Вуков век, Београд: Чигоја штампа.

Младеновић 1989: Александар Младеновић, Славеносрпски језик, Нови Сад - Горњи Милановац: Књижевна заједница Новог Сада - Дечје новине.

Нуорлуото 1989: Juhani Nuorluoto, Jovan Stejić's Language. A Contribution to the History of the Serbo-Croatian Standard Language, Slavica Helsingiensia 8, Helsinki.

Окука 1987: Miloš Okuka, U Vukovo doba, Sarajevo: Veselin Masleša.

Остојић 1976: Бранислав Остојић, Језик Петра I Петровића, Титоград: Црногорска академија наука и умјетности.

Симић 1991: Радоје Симић, О нашем књижевном језику, Никшић: НИП „Универзитетска ријеч”.

Стијовић 1992: Светозар Стијовић, Славенизми у Његошевим песничким делима, Сремски Карловци - Нови Сад: Издавачка књижарница Зорана Стојановића.

Стојановић 2016: Јелица Стојановић, Пут српског језика и писма, Београд: Српска књижевна задруга.

Суботић 1989: Љиљана Суботић, Језик Јована Хащића, Нови Сад: Матица српска.

Сучевић 1914: М. Сучевић, Језик у делима Доситеја Обрадовића, Извештај Српске православне велике гимназије ср. Карловачке за школску годину 1913/14, књ. 55, Сремски Карловци, 5-60.

Толстој 2004: Никита И. Толстој, Студије и чланщи из историје српског књижевног језика, Београд - Нови Сад: Завод за уџбенике и наставна средства - Вукова задужбина - Матица српска.

Унбегаун 1995: Борис Унбегаун, Почеции књижевног језика код Срба, Београд - Нови Сад: Вукова задужбина - Матица српска - Орфелин.

Херити 1983: Питер Херити, Къижевни језик Емануила Јанковића, Нови Сад: Матица српска.

Херити 1999: Питер Херити, Језичка разматраға, Београд - Нови Сад: Завод за уџбенике и наставна средства - Вукова задужбина - Матица српска. 


\section{MILOŠ KOVAČEVIĆ AS A HISTORIAN OF THE STANDARD SERBIAN LANGUAGE}

\section{Summary}

The paper analyzes Kovačević's theoretical and methodological grounds and techniques for the study of language changes which occurred in the $18^{\text {th }}$ and the $19^{\text {th }}$ century. As most dominant features of Kovačević's approach, the author specifies his ability to synthetize, identify the main tendencies in the development of standard language and define similarities and differences that existed between notions of the standard language. All this makes Kovačević's approach closest to that of Radoje Simić.

Key words: Miloš Kovačević, history of standard Serbian language, the notions of the standard language, people's language, Vuk Karadžić, Dositej Obradović, „općena pravilnost" (general systematicity). 